\title{
Identification of Random Amplified Polymorphic DNA Markers Linked to the Co-4 Resistance Gene to Colletotrichum lindemuthianum in Common Bean
}

\author{
Maricilia C. Cardoso de Arruda, Ana Lilia Alzate-Marin, José Mauro Chagas, \\ Maurilio Alves Moreira, and Everaldo Gonçalves de Barros
}

First, second, fourth, and fifth authors: Instituto de Biotecnologia Aplicada à Agropecuária (BIOAGRO), Universidade Federal de Viçosa (UFV), 36571-000 Viçosa, MG, Brazil; first author: Universidade estadual de Mato Grosso (UNEMAT); third author: Empresa de Pesquisa agropecuaria de Minas Gerais (EPAMIG), Viçosa, MG, Brazil; fourth author: Departamento de Bioquímica e Biologia Molecular, UFV, Viçosa, MG, Brazil; and fifth author: Departamento de Biologia Geral, UFV, Viçosa, MG, Brazil.

Accepted for publication 8 March 2000.

\begin{abstract}
de Arruda, M. C. C., Alzate-Marin, A. L., Chagas, J. M., Moreira, M. A., and de Barros, E. G. 2000. Identification of random amplified polymorphic DNA markers linked to the $\mathrm{Co}-4$ resistance gene to Colletotrichum lindemuthianum in common bean. Phytopathology 90:758-761.

New cultivars of the common bean (Phaseolus vulgaris) with durable resistance to anthracnose can be developed by pyramiding major resistance genes using marker-assisted selection. To this end, it is necessary to identify sources of resistance and molecular markers tightly linked to the resistance genes. The objectives of this work were to study the inheritance of resistance to anthracnose in the cultivar TO (carrying the Co-4 gene), to identify random amplified polymorphic DNA (RAPD) markers linked to $\mathrm{Co}-4$, and to introgress this gene in the cultivar Rudá. Popu-

lations $\mathrm{F}_{1}, \mathrm{~F}_{2}, \mathrm{~F}_{2: 3}, \mathrm{BC}_{1} \mathrm{~s}$, and $\mathrm{BC}_{1} \mathrm{r}$ from the cross Rudá $\times$ TO were inoculated with race 65 of Colletotrichum lindemuthianum, causal agent of bean anthracnose. The phenotypic ratios (resistant/susceptible) were $3: 1$ in the $\mathrm{F}_{2}$ population, 1:1 in the $\mathrm{BC}_{1} \mathrm{~s}$, and 1:0 in the $\mathrm{BC}_{1} \mathrm{r}$, confirming that resistance to anthracnose in the cultivar TO was monogenic and dominant. Six RAPD markers linked to the $\mathrm{Co}-4$ gene were identified, four in the coupling phase: OPY $20_{830 \mathrm{C}}(0.0$ centimorgan $[\mathrm{cM}]), \mathrm{OPC}_{900 \mathrm{C}}(9.7 \mathrm{cM})$, OPI $16_{850 \mathrm{C}}(14.3 \mathrm{cM})$, and OPJ01 $1_{1,380 \mathrm{C}}(18.1 \mathrm{cM})$; and two in the repulsion phase: OPB03 $3_{1,800 \mathrm{~T}}(3.7 \mathrm{cM})$ and OPA $18_{830 \mathrm{~T}}(17.4 \mathrm{cM})$. OPY20 ${ }_{830 \mathrm{C}}$ and OPB $03_{1,800 \mathrm{~T}}$, used in association as a codominant pair, allowed the identification of the three genotypic classes with a high degree of confidence. Marker OPY $20_{830 \mathrm{C}}$, which is tightly linked to $\mathrm{Co}-4$, is being used to assist in breeding for resistance to anthracnose.
\end{abstract}

Anthracnose, caused by the fungus Colletotrichum lindemuthianum (Sacc. \& Magn.) Lams.-Scrib., is among the most important diseases of the common bean (Phaseolus vulgaris L.) in Brazil and in other growing regions of the world (17). This disease can cause yield losses of up to $100 \%$ when infected seed is sown in areas with high relative humidity and mild temperatures (21).

Although breeding for resistance to anthracnose has created several resistant common bean cultivars $(27,28)$, new cultivars have to be developed continuously due to the high degree of pathogenic variability of the fungus (24). Cultivar TO, one of 12 differentials used in the identification of races of the anthracnose fungus in common beans (18), has been shown to be resistant to 22 of $25 C$. lindemuthianum pathotypes identified in Brazil (24). The differential cv. TO, which originated from the cross between susceptible cv. Tenderette and the Mexican line Acapulco, carries a dominant resistance gene, originally designated Mexique II and renamed Co-4 (5), that is different and independent of other anthracnose resistance genes $\mathrm{Co}-1, \mathrm{Co}-2, \mathrm{Co}-3, \mathrm{Co}-5$, and $\mathrm{Co}-6(7,34)$. The resistance conferred by $\mathrm{Co}-4$ has proven to be effective against a large number of Latin American isolates of $C$. lindemuthianum and is an important resistance source used by several breeding programs $(1,7$, 17-20,32,33).

Nelson (16) recommended the use of gene pyramiding as a strategy for developing stable resistance and for preventing the out-

Corresponding author: A. L. Alzate-Marin; E-mail address: aalzate@alunos.ufv.br

Publication no. P-2000-0424-02R

(C) 2000 The American Phytopathological Society break of new pathotypes of a pathogen. However, traditional breeding procedures are inefficient for pyramiding resistance genes due to the need for multiple inoculations (14). Pyramiding resistance genes using molecular markers should allow a more efficient selection of resistant plants in segregating populations. Random amplified polymorphic DNA (RAPD) markers (30) linked to anthracnose resistance genes are currently being used by several bean-breeding groups $(2,8-11,31-33)$ to aid the development of disease-resistant cultivars. RAPD markers can facilitate the pyramiding of resistance genes into commercial common bean cultivars, especially if they are tightly linked to the locus containing the resistance allele. Unfortunately, RAPD markers are inherited in a dominant fashion, preventing the identification of heterozygous individuals. However, this limitation can be bypassed by using a RAPD marker linked to a resistance allele in the coupling phase in association with another marker linked in the repulsion phase to the same allele $(2,8,10,33)$.

The main goal of this work was to identify RAPD markers linked to gene $\mathrm{Co}-4$ present in cv. TO using a segregating population derived from the cross Rudá $\times$ TO. Rudá is a commercial cultivar with a carioca seed highly acceptable to consumers in Brazil, but susceptible to most $C$. lindemuthianum pathotypes. The information obtained will be used by our breeding program to pyramid several disease-resistance genes into cv. Rudá.

\section{MATERIALS AND METHODS}

Source of $C$. lindemuthianum isolates and cultural procedures. Pathotype 65 of $C$. lindemuthianum used in this study was 
collected in the state of Minas Gerais, Brazil. It is part of a group of 25 pathotypes collected in different regions of Brazil and identified by Rava et al. (24). The original inoculum was provided by C. A. Rava and A. Sartorato (Rice and Bean Research CenterEMBRAPA, Goiânia, GO, Brazil). Inoculum was increased by cultivating the fungus for approximately 10 days in sterile medium containing young green pods of common bean (22). The identity of the pathotype was confirmed by inoculation onto the 12 bean anthracnose differential cultivars (18).

Parents, crosses, and seed production. Seed from cvs. Rudá and TO was provided by EMBRAPA (Goiânia, GO, Brazil) and CIAT (Tropical Agriculture International Center, Cali, Colombia), respectively. TO is a Mesoamerican cultivar, determinate, with medium dark beige seeds. Rudá is also a Mesoamerican cultivar, indeterminate, with small carioca-type seeds (26). All crosses were performed in the greenhouse. 'TO' was used as the male parent in all crosses. Backcrosses were made to both 'TO' $(\mathrm{BCr})$ and the susceptible parent $(\mathrm{BCs}) . \mathrm{F}_{1}$ plants were selfed to generate $\mathrm{F}_{2}$ seed. Individual $F_{2}$ plants were harvested to generate $F_{2: 3}$ families.

Genetic analyses and evaluation of disease symptoms. The following number of seeds was sown in the greenhouse in a completely randomized design: 27 seeds from each parent, $16 \mathrm{~F}_{1}$ seeds, $171 \mathrm{~F}_{2}$ seeds, 32 seeds from $\mathrm{BCr}$, and 46 seeds from BCs. Fourteen days after sowing, the first expanded trifoliate leaf from each of the 405 plants were inoculated with spores of $C$. lindemuthianum pathotype 65 . Spores $\left(1.2 \times 10^{6}\right.$ conidia per $\left.\mathrm{ml}\right)$ were applied with

TABLE 1. Segregation for resistance to race 65 of Colletotrichum lindemuthianum in the cross Rudá $\times$ TO

\begin{tabular}{|c|c|c|c|c|c|c|}
\hline \multirow[b]{2}{*}{ Pedigree } & \multirow[b]{2}{*}{ Generation } & \multicolumn{2}{|c|}{ No. of plants } & \multirow{2}{*}{$\begin{array}{l}\text { Expected } \\
\text { ratio }\end{array}$} & \multirow[b]{2}{*}{$\chi^{2}$} & \multirow[b]{2}{*}{$P$} \\
\hline & & Resistant & Susceptible & & & \\
\hline Rudá & $\mathrm{P}_{1}$ & 0 & 27 & $\ldots$ & $\ldots$ & ... \\
\hline TO & $\mathrm{P}_{2}$ & 27 & 0 & .. & & 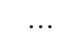 \\
\hline Rudá × TO & $F_{1}$ & 16 & 0 & & & \\
\hline Rudá × TO & $\mathrm{F}_{2}$ & 125 & 46 & $3: 1$ & 0.3295 & 56.60 \\
\hline$F_{1} \times$ & $\mathrm{BCs}$ & 23 & 23 & $1: 1$ & 0.0870 & 76.80 \\
\hline $\mathrm{F}_{1} \times \mathrm{TO}$ & $\mathrm{BCr}$ & 32 & 0 & 1:0 & 0.00001 & 100.00 \\
\hline Rudá $\times \mathrm{TO}^{\mathrm{a}}$ & $\mathrm{F}_{2: 3}$ & $43 \mathrm{RR}: 82 \mathrm{Rr}$ & $46 \mathrm{rr}$ & $1: 2: 1$ & 0.3905 & 82.30 \\
\hline
\end{tabular}

${ }^{a}$ RR corresponds to genotype $\mathrm{Co} 4 \mathrm{Co} 4, \mathrm{Rr}$ to $\mathrm{Co} 4 \mathrm{co} 4$, and rr to $\mathrm{co} 4 \mathrm{co} 4$.

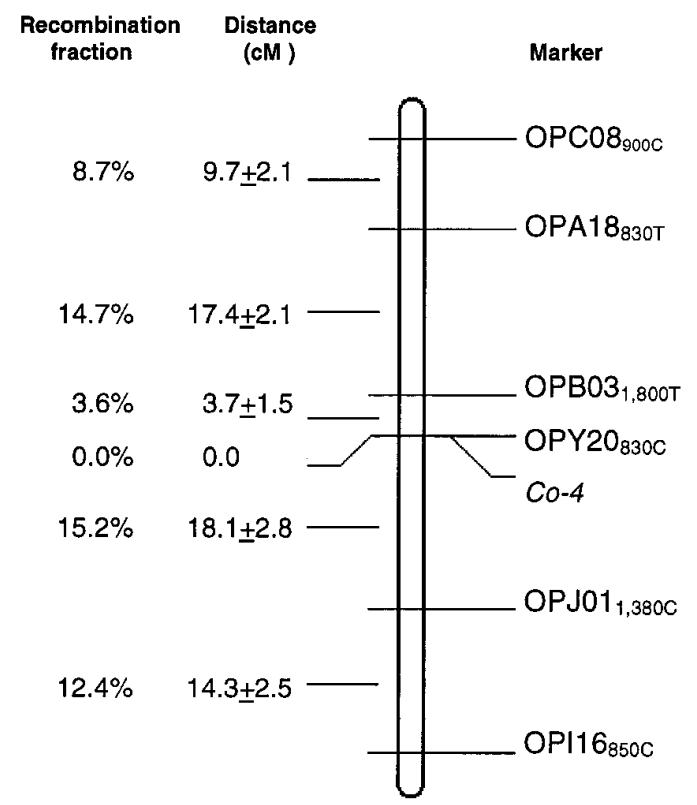

Fig. 1. Relative positions of random amplified polymorphic DNA markers linked to gene $\mathrm{Co}-4$ identified in a segregating population derived from the cross Rudá × TO. a paint brush to one of the primary leaves of 14-day-old plants. The plants were incubated and maintained in a mist chamber (20 to $22^{\circ} \mathrm{C}, 100 \%$ relative humidity) for 7 days and then the disease symptoms were scored visually using a scale of 1 to 9 (23), in which $1=$ plants with no visible symptoms; $2=$ up to $1 \%$ of small lesions in midveins on the lower leaf surface; $3=$ up to $3 \%$ of small lesions in midveins on the lower leaf surface; $4=$ up to $1 \%$ of lesions present in the midvein on the lower and upper leaf surfaces and occasionally in secondary leaf veins; $5=$ up to $3 \%$ of small lesions scattered in midveins and secondary veins on both leaf surfaces; $6=$ more than $3 \%$ of small lesions as described in grade 5 on both leaf surfaces and in the stems and petioles; $7=$ many large lesions scattered on both leaf surfaces and many lesions in the stems and petioles; $8=$ many large coalesced lesions accompanied by tissue breakdown and chlorotic or abscised leaflets, reduced plant growth, and many lesions in the stems and petioles; and $9=$ severely diseased or dead plants.

The resistant (R) phenotype was assigned to plants with no or limited symptoms (grades 1 to 3 ), whereas plants graded 4 or greater were considered susceptible (S). Before inoculation, the healthy primary leaf from each plant was collected and frozen at $-80^{\circ} \mathrm{C}$ for DNA extraction.

DNA extraction and amplification. DNA extraction was conducted according to Doyle and Doyle (6). Amplification reactions were performed in a thermocycler (model 9600; Perkin-Elmer Corp., Norwalk, CT). Each reaction ( $25 \mu \mathrm{l})$ contained $25 \mathrm{ng}$ of DNA; $0.1 \mathrm{mM}$ of each dNTP; $2.0 \mathrm{mM} \mathrm{MgCl}_{2} ; 10 \mathrm{mM}$ Tris-HCl, pH 8.3; $50 \mathrm{mM}$ $\mathrm{KCl} ; 0.4 \mu \mathrm{M}$ of one primer decamer (Operon Technologies, Inc., Alameda, CA); and one unit of Taq DNA polymerase (30).

Each amplification cycle consisted of one denaturation step at $94^{\circ} \mathrm{C}$ for $15 \mathrm{~s}$, one annealing step at $35^{\circ} \mathrm{C}$ for $30 \mathrm{~s}$, and one extension step at $72^{\circ} \mathrm{C}$ for $1 \mathrm{~min}$. After 40 cycles, an extra extension step was performed for $7 \mathrm{~min}$ at $72^{\circ} \mathrm{C}$. Amplification products were analyzed on $1.2 \%$ agarose gels immersed on Tris-borate-EDTA buffer (TBE; $90 \mathrm{mM}$ Tris-borate and $2 \mathrm{mM}$ EDTA, pH 8.0) containing ethidium bromide at $10 \mathrm{mg} / \mathrm{ml}$ (30). DNA bands were visualized under UV light and photographed with the Eagle Eye II photosystem (Stratagene Inc., La Jolla, CA).

Identification of RAPD markers. The Bulked Segregant Analysis technique (15) was used to identify RAPD markers linked to the resistance gene or genes for pathotype 65 . Two contrasting bulks were prepared, each containing DNA from eight homozygous resistant or susceptible $\mathrm{F}_{2}$ individuals. The homozygosity of $\mathrm{F}_{2}$ resistant plants used in the bulks was determined by inoculating all $\mathrm{F}_{2: 3}$ families (11 to 22 plants each). Inoculation conditions and symptom evaluation were performed as mentioned before; however, in this case, spores were sprayed onto plants with a DeVilbiss No. 15 apparatus (DeVilbiss Co., Somerset, PA). For DNA amplification, 567 different primers were used (Operon Technologies, Inc.).

Linkage analyses. Chi-square analyses were used to test the phenotypic segregation of the populations originating from the

TABLE 2. Segregation analyses of random amplified polymorphic DNA $\mathrm{OPY}_{20} 0_{830 \mathrm{C}}, \mathrm{OPC} 8_{900 \mathrm{C}}, \mathrm{OPJ} 01_{1,380 \mathrm{C}}, \mathrm{OPI} 16_{850 \mathrm{C}}, \mathrm{OPB} 03_{1,800 \mathrm{~T}}$, and OPA $18_{830 \mathrm{~T}}$ markers and the $\mathrm{Co}-4$ gene in the $\mathrm{F}_{2}$ and $\mathrm{F}_{2: 3}$ populations in the cross Rudá $\times$ TO

\begin{tabular}{lcccccc}
\hline $\begin{array}{l}\text { Locus } \\
\text { tested }\end{array}$ & Generation & $\begin{array}{c}\text { Observed } \\
\text { ratio }\end{array}$ & $\begin{array}{c}\text { Expected } \\
\text { ratio }\end{array}$ & $\chi^{2}$ & $P$ & \multicolumn{1}{c}{$\mathrm{cM}^{\mathrm{a}}$} \\
\hline $\mathrm{Co}-4$ & $\mathrm{~F}_{2}$ & $125: 46$ & $3: 1$ & 0.3295 & 56.60 & $\ldots$ \\
$\mathrm{Co}-4$ & $\mathrm{~F}_{2: 3}$ & $43: 82: 46$ & $1: 2: 1$ & 0.3905 & 82.30 & $\ldots$ \\
OPY20 $_{830 \mathrm{C}} \mathrm{b}$ & $\mathrm{F}_{2}$ & $125: 46$ & $3: 1$ & 0.3295 & 56.60 & $0.0 \pm 1.1$ \\
OPC08 $_{900 \mathrm{C}}$ & $\mathrm{F}_{2}$ & $123: 48$ & $3: 1$ & 0.8596 & 35.40 & $9.7 \pm 2.1$ \\
OPI16 $_{850 \mathrm{C}}$ & $\mathrm{F}_{2}$ & $120: 51$ & $3: 1$ & 2.1228 & 14.51 & $14.3 \pm 2.5$ \\
OPJ01 $_{1380 \mathrm{C}}$ & $\mathrm{F}_{2}$ & $123: 48$ & $3: 1$ & 0.8596 & 35.40 & $18.1 \pm 2.8$ \\
OPB03 $_{1,800 \mathrm{~T}} \mathrm{c}$ & $\mathrm{F}_{2}$ & $126: 45$ & $3: 1$ & 0.1579 & 69.10 & $3.7 \pm 1.5$ \\
OPA18 $_{830 \mathrm{~T}}$ & $\mathrm{~F}_{2}$ & $120: 51$ & $3: 1$ & 2.1228 & 14.51 & $17.4 \pm 2.7$ \\
\hline
\end{tabular}

a Distance in centimorgans in relation to $\mathrm{Co}-4$ (resistance gene).

${ }^{\mathrm{b}}$ The 830-bp molecular marker linked in the coupling phase (cis) to the Co-4 gene.

c The 1,800-bp molecular marker linked in the repulsion phase (trans) to the Co-4 gene. 
TABLE 3. Amplification of DNA from differential cultivars for common bean anthracnose with random amplified polymorphic DNA primers flanking markers linked to the resistance gene $\mathrm{Co}-4$

\begin{tabular}{|c|c|c|c|c|c|c|c|c|c|c|c|c|}
\hline \multirow[b]{2}{*}{ Molecular marker } & \multicolumn{12}{|c|}{ Differential cultivars ${ }^{\mathrm{a}}$} \\
\hline & 1 & 2 & 3 & 4 & 5 & 6 & 7 & 8 & 9 & 10 & 11 & 12 \\
\hline OPY $20_{830 \mathrm{C}}$ & - & - & - & - & - & - & - & + & + & - & - & + \\
\hline $\mathrm{OPC} 08_{900 \mathrm{C}}$ & + & - & + & + & + & - & + & + & + & - & + & - \\
\hline OPB $03_{1,800 \mathrm{~T}}$ & - & - & - & - & - & - & - & - & - & - & - & - \\
\hline OPI $16_{850 \mathrm{C}}$ & + & - & - & - & - & - & + & + & + & + & - & - \\
\hline OPA $18_{830 \mathrm{~T}}$ & - & - & - & - & - & - & - & - & - & - & - & - \\
\hline
\end{tabular}

a 1 = 'Michelite', 2 = 'MDKR', 3 = 'Perry Marrow', 4 = 'Cornell 49-242', 5 = 'Widusa', 6 = 'Kaboon', 7 = 'México 222', 8 = 'PI 207262', $9=$ 'TO', 10 = 'TU', $11=$ 'AB136', and $12=$ 'G 2333'; $-=$ band absent and $+=$ band present.

TABLE 4. Selection efficiency for resistance to Colletotrichum lindemuthianum pathotype 65 in $171 \mathrm{~F}_{2}$ individuals from the cross Rudá $\times$ TO based on molecular markers

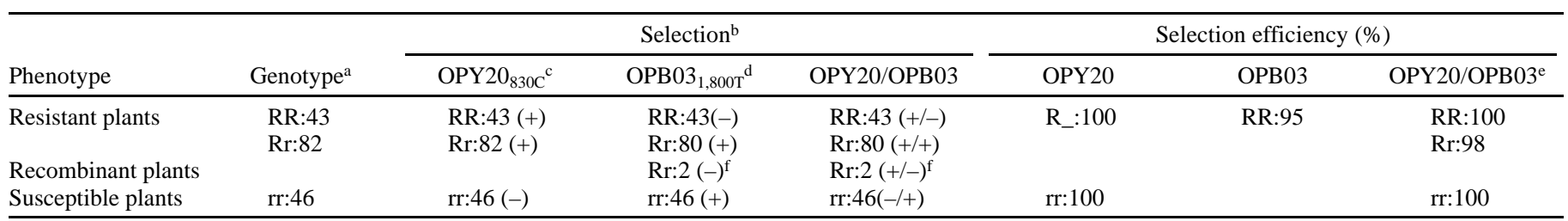

${ }^{a}$ Observed ratios in $\mathrm{F}_{2}$ plants based on corresponding $\mathrm{F}_{2: 3}$ families. RR corresponds to $\mathrm{Co} 4 \mathrm{Co} 4$, Rr to $\mathrm{Co} 4 \operatorname{co} 4$, and rr to $\operatorname{co} 4 \operatorname{co} 4$ individuals.

$\mathrm{b}+=$ band present, $-=$ band absent, and $+/-=$ marker OPY $20_{800 \mathrm{C}}$ present and marker OPB $03_{1,800 \mathrm{~T}}$ absent.

${ }^{c}$ Coupling.

${ }^{\mathrm{d}}$ Repulsion.

e Selection efficiency with combined use of markers in the coupling and repulsion phases to the Co-4 gene.

${ }^{\mathrm{f}}$ Resistant individuals $\operatorname{Rr}(-)$ or $\operatorname{Rr}(+/-)$ are recombinants.

cross Rudá $\times$ TO and to determine possible linkages between the RAPD marker and the resistance gene. Genetic distances between the markers and the resistance gene were determined with the aid of the program MAP-MAKER III (12), using a log of the likelihood ratio (LOD) score minimum of 3.0.

Selection efficiency analyses. The efficiency of RAPD markers to identify resistant or susceptible plants and to determine the genotypic constitution of the resistance locus was determined in the $\mathrm{F}_{2}$ plants based on phenotypic data derived from the respective $F_{2: 3}$ families.

\section{RESULTS AND DISCUSSION}

Cv. TO resistance to $C$. lindemuthianum race 65 . Resistance of cv. TO to race 65 appears to be controlled by a single dominant gene. Chi-square values revealed that a good fit was obtained for the segregation ratio of $3: 1$ in the $F_{2}, 1: 2: 1$ in the $F_{2: 3}, 1: 1$ when the $\mathrm{F}_{1}$ was backcrossed to 'Rudá', and 1:0 when the $\mathrm{F}_{1}$ was backcrossed to 'TO' (Table 1). These results support previous work $(4,7$, $13,20,28,34)$.

Identification of RAPD markers linked to $\mathrm{Co}-4$. The following RAPD markers were linked in the coupling phase to the $\mathrm{Co}-4$ gene in the $F_{2}$ population: OPY $20_{830 \mathrm{C}}(0.0 \pm 1.1$ centimorgans $[\mathrm{cM}])$, $\mathrm{OPC}_{0} 8_{900 \mathrm{C}}(9.7 \pm 2.1 \mathrm{cM}), \mathrm{OPI}_{850 \mathrm{C}}(14.3 \pm 2.5 \mathrm{cM})$, and $\mathrm{OPJ}_{1,380 \mathrm{C}}$ $(18.1 \pm 2.8 \mathrm{cM})$. Two RAPD markers linked in the repulsion phase to the same gene were also identified: OPB03 ${ }_{1,800 \mathrm{~T}}(3.7 \pm 1.5 \mathrm{cM})$ and OPA $18_{830 \mathrm{~T}}(17.4 \pm 2.7 \mathrm{cM})$. The positions of these markers in relation to gene $\mathrm{Co}-4$ is shown in Figure 1. The segregation analyses for each marker is shown in Table 2. This is the first report of molecular markers tightly linked to the $\mathrm{Co}-4$ gene present in cv. TO.

DNA was extracted and amplified with the appropriate primers (Table 3) to determine if the other 11 differential cultivars carry the molecular markers linked to the $\mathrm{Co}-4$ gene in cv. TO. Differential cvs. PI 207262 and G 2333 possess the band OPY20 ${ }_{830 \mathrm{C}}$, which is tightly linked to Co-4. The presence of this marker in ' $\mathrm{G}$ 2333' reinforces the finding that this cultivar carries an allele of the $\mathrm{Co}-4$ gene that was designated $\mathrm{Co}^{2} 4^{2}$ (34). 'PI 207262' affords resistance levels greater than 'TO' (24); therefore, two hypotheses can be raised: 'PI 207262' carries more than one anthracnose resis- tance gene or it carries a different allele at the Co-4 locus (34). Published data show that 'PI 207262' carries duplicated dominant genes for resistance to $C$. lindemuthianum race delta and that only one gene confers resistance to race kappa (29). On the other hand, if 'PI 207262' carries an allele at the Co-4 locus, this allele would be different from $\mathrm{Co}-4^{2}$. This is suggested by the different resistance indexes (RI) between Selection $1308(\mathrm{RI}=97)$, derived from 'G 2333', and 'PI 207262' (RI = 79) (3). Marker OPC08900C (9.7 \pm $2.1 \mathrm{cM})$ was present in most differential cultivars, both Andean and Mesoamerican, suggesting that these cultivars might carry different alleles from gene $\mathrm{Co}-4$. Although this marker is relatively distant from the $\mathrm{Co}-4$ locus, it has been recently detected in the bean line P45, a Brazilian line derived from cv. TO (25).

Selection efficiency. The simultaneous use of RAPD markers in the coupling and repulsion phases to the same gene allows the identification of the three genotypic classes $(2,33)$. Markers OPY20 $0_{830 \mathrm{C}}$ and $\mathrm{OPB} 03_{1,800 \mathrm{~T}}$, linked to the $\mathrm{Co}-4$ gene in the coupling and repulsion phases, respectively, were used for indirect selection of resistant plants as individual markers and as a codominant pair.

The phenotypic and genotypic data of $171 \mathrm{~F}_{2}$ plants derived from the cross Rudá $\times$ TO were obtained by direct analyses of the $F_{2}$ plants and $\mathrm{F}_{2: 3}$-derived families and compared with those obtained with the two markers (Table 4). The selection efficiency for resistant and susceptible plants was $100 \%$ with marker OPY $20_{830 \mathrm{C}}$. This is certainly due to its close linkage to locus $\mathrm{Co}-4$. RAPD marker OPY $20_{830 \mathrm{C}}$ would be very effective identifying phenotypes of resistant and susceptible plants. This marker would be most useful for screening advanced generation $\left(\mathrm{F}_{6}\right.$ or later) lines that are nearly homozygous. The phenotypic efficiency selection of resistant homozygous plants with marker OPB03 $3_{1,800 \mathrm{~T}}$ (identified by the absence of a band) was $95 \%$. However, OPB $03_{1,800 \mathrm{~T}}$ cannot distinguish between heterozygous resistant and susceptible plants. This marker would be most useful to breeders making selections in early generation populations in which one would expect a high frequency of heterozygous plants. The combined use of markers OPY $20_{830 \mathrm{C}}$ and OPB $03_{1,800 \mathrm{~T}}$ as a codominant pair allowed the identification of homozygous and heterozygous resistant plants with selection efficiencies of $100 \%$ and $98 \%$, respectively (Table 4). Our results validate the use of RAPD markers linked in the repulsion and cou- 

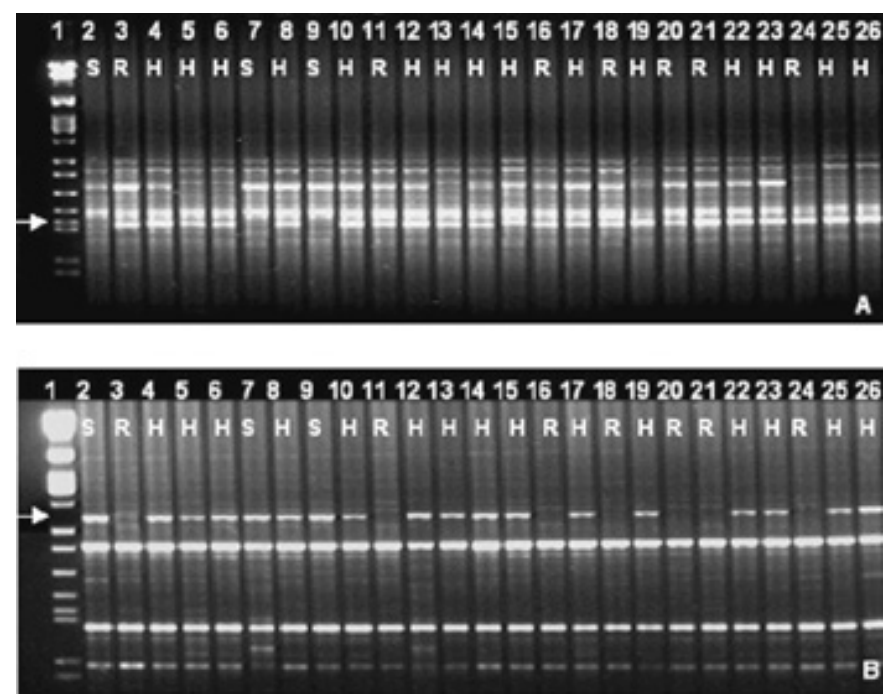

Fig. 2. Electrophoretic analysis of amplification products obtained with primers A, OPY20 and B, OPB03. Lane 1, lambda DNA digested with EcoRI, BamHI, and HindIII (size markers); lane 2, 'Rudá'; lane 3, 'TO'; lanes 11, 16, 18, 20, 21 , and 24, homozygous dominant $\mathrm{F}_{2}$ plants resistant to Colletotrichum lindemuthianum pathotype $65(\mathrm{R})$; lanes 4-6, 8, 10, 12-15, 17, 19, 22, 23, 25, and 26, heterozygous $\mathrm{F}_{2}$ plants resistant to pathotype $65(\mathrm{H})$; and lanes 7 and 9, homozygous recessive $\mathrm{F}_{2}$ plants susceptible to pathotype 65 (S). The arrows indicate markers OPY $20_{830 \mathrm{C}}$ and OPB03 $1,800 \mathrm{~T}$ linked to $\mathrm{Co}-4$ in the $\mathbf{A}$, coupling and $\mathbf{B}$, repulsion phase, respectively.

pling phases to the gene of interest as a codominant pair to predict specific genotypes in segregating populations $(2,8,9,33)$. DNA amplification patterns of $26 \mathrm{~F}_{2}$ individuals analyzed simultaneously with markers OPY $20_{830 \mathrm{C}}$ and OPB $03_{1,800 \mathrm{~T}}$ are shown in Figure 2.

Due to the wide use of the $\mathrm{Co}-4$ gene as a source for resistance to anthracnose in Brazil (24) and in other parts of the world (17), the identification of markers tightly linked to this major gene is an important contribution for breeding programs interesting in pyramiding resistance genes to anthracnose in common beans.

\section{ACKNOWLEDGMENTS}

This work was financed by a grant from FAPEMIG to M. A. Moreira. M. C. C. de Arruda was supported by fellowships from PICD/CNPq and A. L. Alzate-Marin was supported by a FAPEMIG postdoctoral fellowship. We thank J. D. Kelly for the critical reading of the manuscript and suggestions.

\section{LITERATURE CITED}

1. Alzate-Marin, A. L., Baía, G. S., Paula, Jr., T. J., Carvalho, G. A., Barros, E. G., and Moreira, M. A. 1997. Inheritance of anthracnose resistance in common bean differential cultivar AB 136. Plant Dis. 81:996-998.

2. Alzate-Marin, A. L., Menarim, H., de Carvalho, G. A., de Paula, Jr., T. J., de Barros, E. G., and Moreira, M. A. 1999. Improved selection with newly identified RAPD markers linked to resistance gene to four pathotypes of Colletotrichum lindemuthianum in common bean. Phytopathology 89:281-285.

3. Balardin, R. S., and Kelly, J. D. 1998. Interaction between Colletotrichum lindemuthianum races and gene pool diversity in Phaseolus vulgaris. J. Am. Soc. Hortic. Sci. 123:1038-1047.

4. Bannerot, H., Deieux, M., and Fouilloux, G. 1971. Mise en evidence d'un second de resistance totale a l'anthracnose chez le haricot. Ann. Amelior. Plant. (Paris) 21:83-85.

5. Bassett, M. J. 1996. List of Genes-Phaseolus vulgaris L. Annu. Rep. Bean Improv. Coop. 39:1-9.

6. Doyle, J. J., and Doyle, J. L. 1990. Isolation of plant DNA from fresh tissue. Focus 12:13-15.

7. Fouilloux, G. 1979. New races of bean anthracnose and consequences on our breeding programs. Pages 221-235 in: Int. Symp. Dis. Trop. Food Crops. H. Maraite and J. A. Meyer, eds. Universite catholique de Louvain-la-Neuve, Louvain-la-Neuve, Belgium.

8. Haley, S. D., Afanador, L. K., and Kelly, J. D. 1994. Selection for monogenic resistance traits with coupling and repulsion-phase RAPD markers. Crop Sci. 34:1061-1066.
9. Haley, S. D., Miklas, P. N., Stavely, J. R., Byrum, J., and Kelly, J. D. 1993. Identification de RAPD markers linked to a major rust resistance gene block in common bean. Theor. Appl. Genet. 86:505-512.

10. Johnson, E., Miklas, P. N., Stavely, J. R., and Martinez-Cruzado, J. C. 1995. Coupling- and repulsion-phase RAPDs for marker-assisted selection of PI 181996 rust resistance in common bean. Theor. Appl. Genet. 90:659-664.

11. Johnson, W. C., and Gepts, P. 1994. Two new molecular markers linked to bc-3. Annu. Rep. Bean Improv. Coop. 37:206-207.

12. Lander, E. S., Green, P., Abrahamson, J., Barlow, A., Daly, M. J., Lincon, S. E., and Newburgh, L. 1987. MAPMAKER: An interactive computer package for constructing primary genetic linkage maps of experimental and natural populations. Genomics 1:174-181.

13. Mastenbroek, C. 1960. A breeding program for resistance to anthracnose in dry shell haricot beans on a new gene. Euphytica 9:177-184.

14. Michelmore, R. 1995. Molecular approaches to manipulation of disease resistance genes. Annu. Rev. Phytopathol. 15:393-427.

15. Michelmore, R., Paran, I., and Keselli, V. 1991. Identification of markers linked to disease-resistance genes by bulked segregant analysis: A rapid method to detect markers in specific genomic regions by using segregating populations. Proc. Natl. Acad. Sci. U.S.A. 88:9828-9832.

16. Nelson, R. R. 1978. Genetics of horizontal resistance to plant disease. Annu. Rev. Phytopathol. 16:359-378.

17. Pastor-Corrales, M. A. 1985. Enfermedades del frijol causadas por hongos. Pages 172-180 in: FRIJOL: Investigación y Producción. M. López, F. Fernández, and A. Schoonhoven., eds. PNUD-CIAT, Cali, Colombia.

18. Pastor-Corrales, M. A. 1992. Recomendaciones y acuerdos del primer taller de antracnosis en América Latina. Pages 240-250 in: La antracnosis del frijol común, Phaseolus vulgaris, en América Latina. Doc. de Trabajo No. 113. M. Pastor-Corrales, ed. CIAT, Cali, Colombia.

19. Pastor-Corrales, M. A. 1992. Variación patogenica de Colletotrichum lindemuthianum el agente causal de la antracnosis del fríjol y una propuesta para su estandarización. Pages 212-239 in: La antracnosis del frijol común, Phaseolus vulgaris, en América Latina. Doc. de Trabajo No. 113. M. Pastor-Corrales, ed. CIAT, Cali, Colombia.

20. Pastor-Corrales, M. A., Erazo, O. A., Estrada, E. I., and Singh, S. P. 1994. Inheritance of anthracnose resistance in common bean accession G2333. Plant Dis. 78:959-962.

21. Peloso, M. J. Del. 1992. Antracnose do feijoeiro no Estado de Minas Gerais-Brasil. Pages 86-108 in: La antracnosis del frijol común, Phaseolus vulgaris, en América Latina. Doc. de Trabajo No. 113. M. Pastor-Corrales, ed. CIAT, Cali, Colombia.

22. Pio-Ribeiro, G., and Chaves, G. M. 1975. Raças fisiológicas de Colletotrichum lindemuthianum (Sacc. et Magn.) Scrib. que ocorrem em alguns municípios de Minas Gerais, Espírito Santo e Rio de Janeiro. Experientiae 19:95-118.

23. Rava, C. A., Molina, J., Kauffmann, M., and Briones, I. 1993. Determinación de razas fisiológicas de Colletotrichum lindemuthianum en Nicarágua. Fitopatol. Bras. 18:388-391.

24. Rava, C. A., Purchio, A. F., and Sartorato, A. 1994. Caracterização de patótipos de Colletotrichum lindemuthianum que ocorrem em algumas regiões produtoras de feijoeiro comum. Fitopatol. Bras. 19:167-172.

25. Santos, J. B. D., and Ferreira, F. D. 1996. Identificação do alelo Mex. 2 de resistência à antracnose e do alelo para halo escuro em feijão através de marcador RAPD. Braz. J. Genet. 19(suppl.):328.

26. Singh, S. P., Gepts, P., and Debouck, D. G. 1991. Races of common bean (Phaseolus vulgaris, Fabaceae). Econ. Bot. 45:379-396.

27. Singh, S., Pastor-Corrales, M. A., Molina, A., and Otoya, M. 1992. Breeding common bean for resistance to anthracnose. Pages 198-211 in: La antracnosis del frijol común, Phaseolus vulgaris, en América Latina. Doc. de Trabajo No. 113. M. Pastor-Corrales, ed. CIAT, Cali, Colombia.

28. Vidigal, M. C., Cardoso, A., Vieira, C., and Saraiva, L. 1997. Inheritance of anthracnose resistance in common bean genotypes PI 207262 and AB 136. Braz. J. Genet. 20:59-62.

29. Vieira, C. 1988. Doenças e pragas do feijoeiro. UFV Impr. University, Viçosa, Brazil.

30. Williams, J., Kubelik, A., Livak, K., Rafalski, A., and Tingey, S. 1990. DNA polymorphisms amplified by arbitrary primers are useful as genetic markers. Nucleic Acids Res. 18:6531-6535.

31. Young, R., and Kelly, J. D. 1996. RAPD Markers flanking the Are gene for anthracnose resistance in common bean. J. Am. Soc. Hortic. Sci. 121:3741.

32. Young, R., and Kelly, J. D. 1996. Characterization of the genetic resistance to Colletotrichum lindemuthianum in common bean differential cultivars. Plant Dis. 80:650-654.

33. Young, R., and Kelly, J. D. 1997. RAPD markers linked to three major anthracnose resistance genes in common bean. Crop Sci. 37:940-946.

34. Young, R., Melotto, M., Nodari, R. O., and Kelly, J. D. 1998. Markerassisted dissection of the oligogenic anthracnose resistance in the common bean cultivar, "G2333”. Theor. Appl. Genet. 96:87-94. 